\title{
Inflation and Economic Growth in Ethiopia
}

\author{
Mamo Esayas Ambe Abel Wudeneh Abamagal \\ Lecturers, department of economics, wolaiata sodo university, P.O.Box 138
}

\begin{abstract}
This study is focused on inflation of import goods and assesses and identifies the major determinants of import goods inflation in Ethiopia. To achieve this objective the study used time series data (from 1974/75 to 2012/13) to analyze the variables in its multiple linear regression model using ordinary least square (OLS) estimation technique. The model includes; broad money supply, real effective exchange rate \& world oil price as independent variables and import price inflation as dependent variable. Findings of the study suggested that import price inflation in Ethiopia is significantly determined by broad money supply, real effective exchange rate and world oil price. Therefore based on this result revaluation of currency and finding another sources of energy and cooperating with other countries in stabilizing world oil price is recommended for government of Ethiopia.
\end{abstract}

Keywords: inflation , economic growth , multiple linear regression , currency ,M2

DOI: $10.7176 / \mathrm{HRL} / 48-03$

\section{INTRODUCTION}

\section{CHAPTER ONE}

\subsection{Back ground of the study}

In the past 50 years the world's market economies have become increasingly integrated. The share of export and import in the national output has risen for most of the countries. In today's world no nation exists in economic isolation. All aspects of nation's economy are linked to the economies of its trading partner (Carbargh, 2008)

History of inflation began from the time of introduction of money. However, prior to the Second World War inflation tended to occur during and immediately after wars, when government financed the war, or during periods when gold discovers of the significant kind had been made. Such as German hyperinflation of 1923, weak government has attempted to by their way out economics crises by printing vast sum of money (Richard, 1981), this inflation had two important characteristics, It occurred in response to some particular events, such as wars, gold discover or unmanageable economic crises. It lasted only as long as the events with which they were associated, and that was normally not very long.

The Second World War accompanied by rapid world inflation as had been happened often before, the war time inflation continued into post war period. Between 1953 and 1959 retail price in the main industrial countries rise at an average rate of about 2-4 percent per annum. After 1974 the inflation rate quicken in most industrialized counties (ibid)

Although the country has faced different serious macroeconomics shocks, including drought, devastating wars and distorted investment environment the inflation in the country was not miserable and it was very low in the past regime, except, the 1972/73 and 1978/79 oil crises and fluctuations of nonoil import prices. Because price control has kept prices stable. The government was also distributing goods at fixed prices to the public. In addition the lower and pegged exchange rate has also helped to lower the impact of international price like in Ethiopia and makes imports cheaper. During the earlier years of present regime also inflation had been low. (Sisay, 2008), However in the post 2002/03 inflation began to appear as a major problem following the government's move towards less conservative monetary and fiscal policy and state activism as a developmental state in the economy. During the same period, the economy is reported to have recorded a fast growth, export receipts have increased substantially and domestic tax revenue has increased. Government expenditure have grown considerably, there has also been fast increase in money supply mainly as a result of growth in fiscal deficits. Studying the linkage between price developments and various macro-economic variables, therefore enable us to understand the causes of the current inflation in Ethiopia. (Alemayehu G., 2011).

\subsection{STATEMENT OF THE PROBLEM}

Inflation is sustained rise in general price level of goods and services. The definition of inflation concern, not increase in price of a particular product nor for a short period of time. (Mishkin, 2007)

Inflation is bad not because people hate it but because of its serious economic and social effects. It reduces the real income of people especially of those fixed income earners and redistributes income from one group of people to the other group and creates income inequality. Inflation also hinders foreign direct investment because it raises cost of materials and inputs and makers FDI less profitable. Uncertainty about prices and increase in production costs also reduce production. Inflation also results in reduction of exports because of decrease in production and expensiveness of domestically produced goods in international market. At the same time it also results in imports, which adversely affects balance of payment (BOP) of the country. (Jhingan, 1997) sited by 
(Sisay M, 2008).

Structuralists explain the long run inflationary trend in developing countries in terms of structural rigidities, market imperfection and social tension relative inelasticity of food supply, foreign exchange constraints protective measures, rise in demand for food, falling export earnings, hoarding import substation, industrialization and political instabilities.(AyindeO.Eetal, 2010)

Lim C,H.andpapi L. (1997) by using econometric analysis finds that inflation in Turkey is determined by monetary variables (i.e. money and exchange rate) and public sector deficits.

Koech J. and Wynne M.A, (2012) finds that core import prices inflation estimators (excluding oil price) provide little or no predictive power for head line US import price inflation.

There is no agreement on the causes of the high inflation experienced in recent years in Ethiopia. The government state supply bottlenecks, market structure, increased income in the rural sector and international price development especially of petroleum to be the cause of inflation. On the other hand IMF and most economists argue that inflation in Ethiopia is caused due to increased demand caused by expansion in money supply and increased remittance. In addition deficit is also regarded as a cause of the inflation. In short the government attributes inflation to supply factors while international organization and most economists attribute inflation to demand factors (Sisay m., 2008)

Sisay M. (2008) finds that inflation in Ethiopia is in the long run due to structural, monetary expansion lending rates and expectation. On the other hand exchange rate one quarter lagged money supply; gas oil prices and deficit have been found to have no significant impact on inflation in the long run.

Asayeheng D. (2009) finds that main determinant of inflation in Ethiopia are real GDP, exchange rate, domestic landing in ternate rate.

Kibrom T. (2008) states that the most important determinant of inflation in the long run are mainly domestic monetary development while cost push factors are the force behind short run inflation. He also stated that in the long run domestic food price influenced mostly by income growth, inflation expectation, money supply growth and increase in international food price. While he finds determinant of non-food inflation are found to be inflation expectation, money supply growth and interest rate. He also states in the short run, both demand and supply appear important in the current inflationary process, with supply factors having the edge over the demand factors.

Imports share of GDP is increasing in Ethiopia in high rate from 15\% in 1988/89 to 33.3\% in 2012 by amounting $\$ 9.498$ billion. Ethiopia imports food, live animals, petroleum and petroleum products, chemical, machines, motor vehicles, cereals and textiles. (Indexmundi, 2013)

Due to small economic size, production in developing countries is heavily dependent on imported raw materials and no reasonable domestic substitution because of this reason it is one of the major component of their output (Porter and Ranney, 1982). They are facing the problem of BOP deficit due to their high import and inability of their export to subsidize this import. Subsiding this leads to high public debt and budget deficit.

However, amazingly there is no research on determinants of inflation on import component of output in Ethiopia unlike other components of output like food, agriculture, etc. And this appears to be relatively under researched topic, which is a bit surprising as most of the relative price shocks that seem to necessitate the construction of core inflation measure are to the prices of goods that are traded in global market. Therefore this research try to fill this gap and it is pioneer in this regard.

\subsection{Research question}

This research answer questions like;

$\checkmark$ Does a determinant of import goods inflation differ from determinants of the general inflation?

$\checkmark$ What are the significant determinations of import goods inflation?

\section{4 objectives of the study}

The general objective of the study is to identify the major determinants of import goods of inflation in Ethiopia .

* Specific objectives are;

$\checkmark$ To analyze the trend of import goods inflation in Ethiopia

$\checkmark$ To assess the impact of real exchange rate, global inflation, money supply and world oil price on import goods inflation of Ethiopia.

$\checkmark \quad$ To suggest possible course of actions to remedy the problem.

\subsection{Significance of the study}

Modeling inflation and identifying its determinants is necessary for a number of reasons. It is important from the point of view of poverty alleviation and social justice. Furthermore inflation can discourage savings, if the rate of return on savings does not reflect the increase in the level of prices. The uncertainty about future prices can also cause unexpected gains and losses in trade and industry, thus, discourage long term contracts and investment. 
Therefore, this study has the following purposes. First the study act as a case study in Ethiopian import goods inflation for the time periods from 1974/75 to 2012/13. The study also serves as a mirror in showing the major forces causing import goods inflation in Ethiopia. Most importantly the study is expected to raise the interest of scholars to work on import goods inflation. The identification of the key determinants of import goods inflation helps policy makers with appropriate ways of intervention for controlling inflation.

\subsection{Scope of the study}

This study focused only on macroeconomic determinants of import goods inflation and ignores structural variables like structural rigidities, market imperfection, hoarding import substation and political instabilities and it also ignore microeconomics variables like wage. It also focuses only on quantitative variables and do not cover qualitative variables like structural rigidities, market imperfection and consumers test. This study specifically focused on the trend of import goods inflation and effect of money supply, exchange rate and world oil price. The study used data of the two regimes (i.e. Derg regime and current FDRE regime) in other words it includes data from 1974/75-2012/13.

\subsection{Hypothesis of the study}

Based on different theories and findings the independent variables are affect import goods inflation positively and negatively; Increase in money supply increase aggregate demand and so increase price level. Rise in world oil price increase cost of production and cause cost push inflation. Increase in exchange rate increase cost of import and this finally lead to import goods inflation.

\subsection{METHODOLOGY OF THE STUDY}

\section{CHAPTER TWO}

\subsubsection{Data Type and Source}

This study used only secondary data which is time series data type from 1974/75 to 2012/13. The data had been collected from national bank of Ethiopia (NBE) Ethiopian economics association (EEA) ministry of finance and development (MOFED) and external sources like; world bank, world trade organization, IMF and international journals and publications.

\subsection{Method of Data Analysis.}

The study used descriptive statistics like graph and table to analyze the trend of import goods inflation and time series econometrics using ordinary list square method to analyze the determinants of import price inflation.

\subsection{Model Specification}

Economic literature on inflation provide some models that incorporate demand side and supply side factors "(Hassan et al, 1995; Khan and Qasim, 1996; Callen and Chang, 1999; Bokil and Schmelfenning, 2005 and Khan and Schmelfenning, 2006)" Abdullah M. and Kacim R. 2009. Abdullah and Kacim, 2009; Lin and Papi 2009 andKibrom, 2008 used different multiple linear regression models to estimate determinants of inflation in Pakistan, Australia and Ethiopia respectively. Based on these this study used multiple linear regression model including some demand side and supply side as well as exogenous factors to estimate the determinants of import goods inflation in Ethiopia.

\section{$\operatorname{lnIIt}=B_{0}+\ln \beta_{1} M_{2} t+\ln \beta 2 R E E R+\ln \beta_{3} W O P t+U t$}

Where, IIt $=$ import goods inflation at time $\mathrm{t}, \mathrm{M} 2 \mathrm{t}=$ broad money supply at time $\mathrm{t}$

$\mathrm{REER} t=$ real effective exchange rate at time $\mathrm{t}$,

$$
\mathrm{WOPt}=\text { world oil price at time } \mathrm{t} . \quad \mathrm{Ut}=\text { the error term }
$$

The hypothesized sign of the parameters of the estimators are B1, B2\& B3 $>0$.

\section{CHAPTER THREE}

\subsection{Model Specification, Estimation Results and Discussion}

\subsubsection{Model specification}

The main objective of this study is to show the functional relationship between import price inflation and its determinants. Inflation which is proxy by import price is the dependent variable in the model while the explanatory variables are broad money supply (M2), real effective exchange rate (REER \& world oil price (wop).

Then the models are as follows;

\subsubsection{DESCRIPTION OF VARIABLES}

$$
\ln I M P=\beta 1 \ln M 2+\beta_{2} \ln R E E R+\beta_{3} \ln W O P+U_{i}
$$

* Import price: import price is taken as proxy for import price inflation because we could not find time series data on consumer price index of import goods nor we find import inflation data. Therefore, since 
increase in price means increase in inflation and the reverse also true import price is used in the place of import inflation. Inflation due to an increase in the price of imports. As the price of imports increase, prices of domestic goods using imports as raw materials also increase, causing an increase in the general prices of all goods and services. Imported inflation may be caused by foreign price increases or depreciation of a country's exchange rate.

* Broad money supply $\left(\mathbf{M}_{2}\right)$ :- Money is that good which serves directly as a medium of payments. In financially developed economies, this role is performed by currency held by the public and the public's checkable deposits in financial institutions, mainly commercial banks, with their sum being assigned the symbol M1 and called the narrow definition of money. The checkable or demand deposits in question are ones against which withdrawals can be made by check or debit cards. The broad definition that has won the widest acceptance among economists is known as (Milton) Friedman's definition of money or as the broad definition of money. It defines money as the sum of currency in the hands of the public plus all of the public's deposits in commercial banks. The latter include demand deposits as well as savings deposits in commercial banks. Friedman's definition of money is often symbolized as M2 (Jagdish H., 2009). Especially monetarists strongly believe that money supply has a big impact on the inflation process on the economy. Hence it is incorporated in the model to see its impact on the inflationary conditions of the country. Money supply is expected to be positive since increase in the money supply increases aggregate demand and this rise in aggregate demand leads to demand pool inflation given that the aggregate supply does not increase due to different time lags and supply bottle necks.

* Real Effective Exchange rate:-Exchange rate adjustments are potential source of inflation. The adjustment in the relative price of tradable and non-tradable implied by devaluation and revaluation often involves an increase and decrease in the overall price level respectively. It has direct impact on inflation by affecting the terms of trade (relative price of import and export) and Bop position of the countries and its expected sign is positive because devaluation in the exchange rate means the relative price of dollar to Ethiopian birr become higher this makes imports expensive.

* World oil price: world oil price is the price of the crude oil at the global market. It is the world average crude oil price. A sharp increase in the price of crude oil causes an exogenous inflationary shock and the impact of this will be greatest when a particular country is a large scale net importer of oil. A significant rise in global oil prices would have many other inflationary effects: for example increasing the cost of heating oil, aviation fuel, plastics, chemicals, as well as raising the material cost of all firms. Its expected sign is positive.

\subsubsection{MODEL ESTIMATION}

Since time series data exhibit consistent trend overtime, potential problem can arise when classical regression model applied to the variable. Therefore before starting the regression of the data it is important to take the stationary, co-integration, autocorrelation, multicolinearity test.

\subsubsection{Unit root test}

First a regression based on non-stationary time series explains the relationship during the study period only. This means that it's impossible to infer about the long run relationship of the variables. In addition, regression of nonstationary time series on another non-stationary time series may lead to spurious regression. In economics a time series that has a unit root is known as random walk which is an example of non-stationary time series. A nonstationary time series can be change to stationary by differencing the variable. If time series is differenced once and the differenced series is integrated of order one, denoted by I(1). Similarly if the original series has to be differenced twice before it become stationary the original series is integrated of order two or I(2). In general if a time series has to be differenced d time, it is integrated of ordered or $\mathrm{I}(\mathrm{d})$. By conversion, if $\mathrm{d}=0$ the resulting $\mathrm{I}(0)$ process represents a stationary time series (Gujarati, 1995).

\subsubsection{The Test for unity root}

If we assume the data generating process (DGP) to be given by $\mathrm{y}_{\mathrm{t}}=\rho \mathrm{y}_{\mathrm{t}^{-1}}+\ldots$. (1).

Where $\varepsilon_{t}$ NID $\left(0,{ }^{2}\right)$, the DF test is to test on the size of the coefficient $\rho$. That is, whether $\rho=1$ or not (Adam, 1992).

If we subtract $\mathrm{y}_{\mathrm{t}^{-1}}$ from both sides of equation (1), we get $\Delta \mathrm{y}_{\mathrm{t}}=\pi \mathrm{y}_{\mathrm{t}-1}+\varepsilon_{\mathrm{t}} \ldots 2$

Where $\pi=\rho-1$. The null hypothesis is $\mathrm{H}_{0}: \pi=0$ (or unit root).

If we add a constant in equation (2), we get

$\Delta \mathrm{y}_{\mathrm{t}}=\partial_{0}$

If a time trend is further included

$\Delta \mathrm{y}_{\mathrm{t}}=\partial_{0}+\mathrm{B}_{\mathrm{t}} \pi \mathrm{y}_{\mathrm{t}-1}+\varepsilon_{\mathrm{t}} \ldots .4$

In (3) and (4) the null hypothesis is $\mathrm{H}_{0}: \pi=0$ the null, therefore, it means that we have a stationary series.

If there are more than one unit root, then testing for a single unit root will be misleading. Therefore, following pantula's principle, it is better to start with higher order unit roots by applying the DF test to the first difference 
of the series. If the result is rejection, then we move to test the given variable at level. If the residuals are serially correlated, which is not unusual for such a DGP, the residual variance not be used (Sjoo, 1997). This is solved by using the ADF test.

Table1. Unit root test at level

\begin{tabular}{|l|l|l|l|l|l|}
\hline No & variable & Without drift & With drift & With drift \&trend & Order of integration \\
\hline 1 & lnimp & -0.225 & -2.637 & -1.889 & - \\
\hline 2 & Lnm2 & -4.034 & -2.975 & -1.728 & - \\
\hline 3 & lnreer & -0.794 & -1.076 & -2.410 & - \\
\hline 4 & lnwop & -1.190 & -0.762 & -1.417 & - \\
\hline
\end{tabular}

Table 2: unit root test at First differences

\begin{tabular}{|c|c|c|c|c|c|}
\hline No & variables & Without drift & With drift & With drift \& trend & Order of integration \\
\hline 1 & $\Delta^{\operatorname{lnimp}}$ & 3.804 & 3.749 & $3.676^{*}$ & $\mathrm{I}(1)$ \\
\hline 2 & $\Delta \mathrm{Lnm} 2$ & 0.982 & 3.165 & $4.333^{*}$ & $\mathrm{I}(1)$ \\
\hline 3 & $\Delta \ln r e e r$ & 3.885 & 3.886 & $4.045^{*}$ & $\mathrm{I}(1)$ \\
\hline 4 & $\Delta \operatorname{lnwop}$ & 4.124 & 4.389 & $4.374 *$ & $\mathrm{I}(1)$ \\
\hline \multicolumn{6}{|c|}{ Critical values } \\
\hline \multicolumn{2}{|c|}{ percent } & \multicolumn{2}{|c|}{ Without drift } & With drift & With drift and trend \\
\hline \multicolumn{2}{|l|}{$1 \%$} & \multicolumn{2}{|l|}{-2.644} & -2.449 & -4.288 \\
\hline \multicolumn{2}{|l|}{$5 \%$} & \multicolumn{2}{|l|}{-1.950} & -1.694 & -3.560 \\
\hline \multicolumn{2}{|c|}{$10 \%$} & \multicolumn{2}{|l|}{-1.604} & -1.309 & -3.216 \\
\hline
\end{tabular}

*Shows the null is rejected at $5 \%$.

* As shown in table 1 above, the null hypothesis which states the time series has unit root is accepted for all variables with trend and drift. However, as shown in table 2, the null hypothesis is rejected for the variables all variables with trend ad drift at the $5 \%$ conventional level of significance. These shows all the variables included in the model are non-stationary at level and stationary at the first difference. Hence, co integration test can be conducted for the model.

\subsubsection{Co-integration}

In order to obtain both the short run dynamics and the long-run relationship, one can appeals to what is known as co-integration. The concept of co-integration implies that even if many economic variables are non-stationary, there linear combination may be stationary. Therefore, the important thing is to test whether integrated variables co-integrated so that a meaningful long run relationship can be established

\subsubsection{Test to co-integration}

Though there are different tests for co-integration, we focus on the two step procedure by Engle and Granger.

The Engle - Granger two step procedure

Given $\mathrm{y}_{\mathrm{t}} \sim \mathrm{I}(1)$ and $\mathrm{x}_{\mathrm{t}} \sim \mathrm{I}(1)$, then

Step 1: Do OLS on $\mathrm{Y}_{\mathrm{t}}=\partial+\mathrm{Bx}_{\mathrm{t}}+\varepsilon_{\mathrm{t}}$ (Regression on levels) which is called co-integrating regression: save the residual from this regression.

Step 2: Test whether $\hat{E}_{t}$ (the estimated residual) is I (o) or I(1)

This can be done by ADF test which is formed as $\Delta \hat{\mathrm{E}}_{\mathrm{t}}=\partial_{0}+\pi \hat{\mathrm{E}}_{\mathrm{t}-1}+\sum \Delta \hat{\mathrm{E}}_{\mathrm{t}-1}+\mathrm{u}_{\mathrm{t}}$

The null hypothesis here is $\pi=0$ (unit root) and the alternative is that the variables are co-integrated. The relevant test statistics used here is different from the usual unit root test on a variable because here we have a derived variable.

The major problems in the above procedure are: the assumption of only one co-integrating vector, the choice of logs in the ADF test and the assumption of a common factor in the dynamic of the system. 
Table 3; Residual unit root test

\begin{tabular}{|l|l|l|l|}
\hline variables & Without drift & With drift & With drift \&trend \\
\hline residual & 2.655 & 2.728 & 2.874 \\
\hline
\end{tabular}

Critical values of the residual test

\begin{tabular}{|l|l|l|l|}
\hline percent & Without drift & With drift & With drift \&trend \\
\hline $1 \%$ & -2.642 & -2.445 & -4.279 \\
\hline $5 \%$ & -1.950 & -1.692 & -3.556 \\
\hline $10 \%$ & -1.604 & -1.308 & -3.214 \\
\hline
\end{tabular}

The existence of co-integrating relationship implies the long run relationship between the variables. There are a number of methods for testing co-integration but this study use the Engle-Granger two step procedures.

The Engle-Granger methodology determines whether the residual is stationary or not. If this residual, which is the Linear combination of the variable is stationary, then the variables are said to be co-integrated, that is, they have long run relationship.

\subsubsection{Multicolinearity and Autocorrelation test}

One of the assumptions of classical linear regression model (CLRM) is that there is no perfect co linearity among some or all explanatory variables. If the explanatory variables are perfectly linearly related to each other, the problem of multi co linearity will arise. Recently, however, the term multi co linearity is used in broader sense to include the case of perfect co linearity as well as the case where the explanatory variables are highly linearly related. Without considering the problem of multi co linearity will result in wrong conclusion because of it will create so many problems such as large variance and standard error of OLS estimators, wider confidence interval, insignificant " $t$ " value and high $\mathrm{R}$ square value and so on. There for it is important to deal with this problem using variance inflation factor (VIF) as dedicating mechanism (Gujarati, 1995).

The result of multicolinearity test indicates that the mean value of variance inflation factor is 2.19 very much less than 10 and indication of absence of multicolinearity.

The autocorrelation test of Durbin-Watson test shows as Durbin-Watson d-statistics $(4,38)=1.70$ which is close to two hence there is no autocorrelation problem.

\subsubsection{ESTIMATION RESULT}

The model based on stationary time series data at their first difference is estimated by ordinary least square estimation method at $95 \%$ confidence interval result as follows:

\begin{tabular}{|l|l|l|l|l|}
\hline Variable & Coefficient & Standard error & t-value & p-value \\
\hline Dlnm2 & -0.1478 & 0.0389 & -3.80 & 0.001 \\
\hline Dlnreer & 0.5776 & 0.1112 & 5.19 & 0.000 \\
\hline DlnwOP & 0.2618 & 0.7205 & 3.63 & 0.001 \\
\hline C & 1.6858 & 0.7496 & 2.25 & 0.031 \\
\hline Number of obs $=\quad 38$ & & \\
F $(3, \quad 34)=30.73$ & & \\
Prob $>$ F $=0.0000$ & & \\
R-squared $=0.7306$ & & \\
Adj R-squared $=0.7068$ & & \\
\hline
\end{tabular}

The coefficient of determination $\left(\mathrm{R}^{2}\right)$ indicates that the overall significance of the model is high which indicates good model specification which means many important variables are within the model it does imply the variables in the model are important since the F-test indicates the existence of significant variables.

The sign of only two of the variables (i.e., real effective exchange rate and world oil price) are as expected (i.e., having positive sign the same as the hypothesis) and the variables (i.e broad money supply) have negative sign opposed to the hypothesized positive sign. Based on the regression result real effective exchange rate, broad money supply \&world oil price have statistically significant impact on the import price. Out of the total variation in consumer price index 73.06 percent of the variation is explained by the independent variables in the model. This implies the missing of important variables keeping the model significant.

The coefficient of the variables indicate that a unit increase in independent variables have impact on import price inflation with their respective coefficient.

From the above regression table a unit increase in the first difference of real effective exchange rate is followed by 0.1405 increases in the import price and a unit increase in the first difference of world oil price is followed by 0.0024 increases in the import price keeping other things constant. Generally both monetarist and exogenous factors have positive effect on the country import price inflation.

According to the above result the residual from the long run model is stationary at level, implying that the variables under consideration have a long run or equilibrium relationship. Thus, the long run structural equation 
derived from the co-integrating vector is not spurious rather, it is meaningful and it can be presented as.

$$
\begin{array}{cccc}
\text { LnIMP }=1.68-0.15 & \text { LnM2+0.58 } & \text { LnREER+0.26 } & \text { LnWOP+ et } \\
\text { T: }(2.25) & (-3.80) & (5.19) & (3.63) \\
\text { SE: }(0.7496) & (0.0389) & (0.1112) & (0.7205)
\end{array}
$$

\section{1.5 Interpretation of the Econometrics Result of the long run model}

The result of the regression indicates the sign of the coefficients of both DREER and DWOP which are proved significant is positive. This positive sign is in line with economic theory. The positive coefficient of real effective exchange rate indicates that a $1 \%$ increase in real effective exchange rate means $57.76 \%$ increase in price of dollar which in turn increases in price of import. The positive coefficient of world oil price indicate that the price of crude oil a $1 \%$ increase cost of production in any country increase which lead to $26.18 \%$ increase in price of products. Moreover oil is one of major imports of our country therefore increase in price of oil is directly increased in price of aggregate import. Finally, the estimated model show that money supply showed unexpected sign (i.e. the increase of money supply reduces import price inflation) but it found that they are statistically significant. Because of the following reasons;

In a recession, there may be much spare capacity in the economy. Therefore, an increase in the money supply merely helps to get unemployed resources used in the general economy. Therefore, in the case of a recession, increased money supply is unlikely to cause inflation.

In a liquidity trap, interest rates fall to zero but this doesn't prevent people saving. In this situation there is a fall in the velocity of circulation and this can cause deflation. In this situation, increasing the money supply will not necessarily cause inflation.

In a depressed economy (liquidity trap) this correlation breaks down because of a fall in the velocity of circulation. This is why in a depressed economy Central Banks can increase the money supply without causing inflation. This occurred in US between 20087 \& 11. - Large increase in money supplies no inflation.

As stated before the researcher was unable to get researches done on determinants of import price inflation. Therefore, the researcher is unable to compare the result of this study with the same researches done in the topic. However, we can compare with findings of researches done on related topics. Result of the study is to some extent in line with the finding of Asayehgn D. (2009) done on determinants of general inflation. Asayehyn finds import price, Real exchange rate and money supply as determinants of inflation. On the other hand, it contradicts with the result of Kibrom T. (2008), Sisay M. (2008) and Durevil D. et al (2010) conducted on determinants of food price, inflation dynamics and food price, and determinants of inflation respectively. Since Kibrom find real income, money supply, expected inflation and international inflation as determinants of food price while Durevil finds world inflation as the only factor behind the long run evolution of domestic prices whereas, Sisay finds REER, WOP, and deficit as insignificant.

\section{Conclusion and Recommendations}

\section{CHAPTER FOUR}

\subsection{Conclusion}

- In this paper, an attempt was made to study the determinants of import price inflation in Ethiopia by using both theoretically and empirically review of different countries and it also assessed the overall macro economic performance of Ethiopia economic growth for the last three decade and with due emphasis given to import price inflation of the country.

- The study analyzed the determinants of import price inflation in Ethiopia by using data that ranges from 1975-2012. In order to do so import price inflation is taken as dependent variable proxy by import price and real effective exchange rate, broad money supply\& world oil price as independent variables using ordinary least square estimation technique.

- The study also used descriptive statistics like graph and table to analyze the trend of import goods inflation and time series econometrics using ordinary list square method to analyze the determinants of import price inflation. The result reveals that the import price inflation is more stable and higher in the Derg regime than the present regime. While it is lower on average and more unstable alternating between positive and negative consisting both the largest and the lowest values.

- Out of the variables real effective exchange rate and world oil price are found to have positive significant impact on import price inflation, while broad money supply found to be negative significant impact on import price inflation. Generally, the result of the study indicates that import price inflation in Ethiopia is significantly determined by monetarist and exogenous factors.

\subsection{Recommendations}

$>$ Based on the findings of the study the following policy implication can be drawn

* Real effective exchange rate found to be significant determinants of import price inflation. The central 
bank should depreciate the domestic currency in line with trade partners to control imported inflation since import shares almost one third of the country's output.

* Since world oil price is found to be significant determinant of inflation the Ethiopian government should to obtain the way of decrease its import of oil since it cannot control the price of oil. To do so the government should search for other alternative source of power and increase its budget in searching oil in the country.

* The Ethiopian government should also coordinate with other countries in controlling world oil price.

* National bank of Ethiopia should be cautious in controlling money supply to control the problem of inflation on imported goods, since increase in money supply decrease inflation the economic position (boom or recession) of the country should be seen during particular situation.

\section{References}

$>$ Alemayehu G. (2011). Readings on the Ethiopian Economy. Addis Ababa University press, Addis Ababa.

$>$ Amadeo K. (2014). Types of inflation.About.com.

$>$ Asayeheng D. (2009).Economic Growth for inflation: the Ethiopian Dilemma. Working paper, Dominica University of California.

$>$ Ayinde O.E., Olatunji G.B., Ometesho O. A. \&Ayinde K. (2010).Determinants of inflation in Nigeria: a cointegration approach. Working paper, university of Lliorin. Nigeria

$>$ Duravill D., Loening J. \&Birru Y. A. Inflation dynamics and food prices in Ethiopia. Working paper, University of Gothenburg.

$>$ Gujarati D. (1995), Basic econometrics, New York forth edition McGraw-Hill Companies

$>$ Kibrom T. (2008). The sources of the recant inflationary experience in Ethiopia. Working paper, Addis Ababa University.

$>$ Koach J.\& Wynne M.A. (2012).Core import price inflation in the United States, Working paper, Federal Reserve Bank of Dollars.

$>$ Lim C. H. \&Papi L. (1997).An Econometric Analysis of the determinants of inflation in Turkey.Working paper, International Monetary Fund.

$>$ Jagdish H. (2009). Monetary economics $2^{\text {th }}$ edition .Roughledgetayler and Francis group London and new york.

$>$ Jhingan M. C. (1997). Monetary economics $4^{\text {th }}$ edition, Virinda publication. India

$>$ Mishkin, (2007).The economics of money, banking, and financial markets seventh edition. Colombia University

$>$ Mohinudeen R. (2010). Theories of inflation and its economic consequences, Tutebox

$>$ Sisay M. (2008). Determinants of recent inflation in Ethiopia. Working paper, Unity University College

$>$ Trading economics, (2013).Ethiopia imports.

$>$ White L. H. (2008). Inflation .http://www.econlib.org

$>$ www.indexmundi.net. (2013). Ethiopian economy profile

$>$ www.tutor2u.net. (2003). Inflation essentials 